\title{
Monensin feeding trial with young growing bulls
}

\author{
MIKKO TUORI and LIISA SYRJÄLÄ-QVIST
}

Department of Animal Husbandry, University of Helsinki, 00710 Helsinki 71

\begin{abstract}
The effect of monensin on growth and feed utilization was studied in male calves of milk breeds, mainly Ayrshire. After weaning they were kept in an unheated loose-housing type shed divided into four strawbedded pens. The experiment was started at the age of $2-3$ months and lasted 16 weeks. A concentrate mixture and grass silage were offered ad libitum. The concentrate given to the test groups had a monensin content of 35 $\mathrm{ppm}$. Monensin lowered the feed consumption: in the control and test groups the intake of concentrate was 3.9 and $3.7 \mathrm{~kg} \mathrm{DM}$, respectively, the silage intake was 0.8 and $0.7 \mathrm{~kg}$ DM, the fattening feed unit intake was 4.65 and 4.36, and the ME 54.4 and 50.9 MJ per day. The live weight gain was not affected (1328 and 1329 $\mathrm{g} / \mathrm{d})$. Monensin improved the feed conversion rate by $6 \%$. The animals in the test groups were slightly cleaner than the animals in the control groups.
\end{abstract}

\section{Introduction}

Monensin, a polyether antibiotic produced by Streptomyces cinnamonensis, is widely used as a feed additive for ruminants, since it improves their feed utilization (GILL et al. 1976, RAUN et al. 1976). The mechanism of its influence is not fully understood. The most obvious effects of monensin are an increase in the proportion of propionic acid and decreases in acetic and butyric acids in the rumen (RAUN et al. 1976, RICHARDSON et al. 1976).

Some studies indicate that monensin increases the digestibility of energy, protein and especially of fibre (JOYNER et al. 1979, BEEDE et al. 1980, HORTON 1980, HORTON and NICHOLSON 1980, HORTON et al. 1980, WEDEGAERTNER and JOHNSON 1980). Decreased methane production has been noted by JOYNER et al. (1979), WEDEGAERTNER and JOHNSON (1979) and THORNTON and OWENS (1981), but not by GARRETT et al. (1980), who observed instead that monensin decreased fasting heat production and increased the content of net energy for maintenance in the feed.

Most feeding trials have been carried out with beef breed bulls or steers. In Finland beef production is based mainly on cattle of milk breeds. Thus it was considered necessary to test the effect of monensin with bulls of the milk type breeds used in this country.

Monensin (trade mark Rumensin) used in this experiment was supplied by Elanco, Helsinki and produced by Eli Lilly S. A. France. 


\section{Experimental design}

The feeding experiment comprised 60 bull calves. It lasted 16 weeks, from May to September, and was carried out at a private farm in Central Finland. The calves were obtained at the age of 2-4 weeks. There were 42 pure Ayshire calves; the others were Friesian, Finncattle or crosses with beef breeds. The calves were weaned after reaching a concentrate intake of about $1 \mathrm{~kg}$ and moved to a covered unheated cattle shed with straw-bedded floors. One week before the start of the experiment the calves were divided among four pens. First they were grouped into two blocks according to live weight. Within the blocks the calves were then allotted at random to two groups, test and control. At the beginning and end of the experiment the animals were weighed on two consecutive days, otherwise once every fourth week.

\section{Feeds and feeding}

The bulls were group-fed twice a day with grass silage and a concentrate mixture, both ad lib. The concentrate mixture was a commercial compound feed for beef cattle under the age of 6 months (barley + oats $68 \%$, protein conc. $18 \%$, molasses $5 \%$, minerals $3 \%$, other components $6 \%$ ) with or without $35 \mathrm{ppm}$ monensin in air dry feed. The silage was autumn grass (timothy- and cocsfootdominated swards), partly prewilted and ensiled in clamp silos using a mixture of hydrochloric acid and formic acid as preservative. Silage refusals were removed and weighed daily, the concentrate was offered all the time.

\section{Feed sampling and analyses}

Samples of the concentrate mixture were taken daily and pooled in single fourweek samples. Silage samples were taken with a sampling drill at the beginning of each four-week period.

The ordinary Weende analysis (PALOHEIMO 1969) was made on each feed sample (Table 1). The in vitro organic matter (OM) digestibility of the silage was measured (TILLEY and TERRY 1963) and its volatile fatty acids (VFA) were determined by gas chromatography according to HUIDA (1973). The dry matter (DM) content of the silage was corrected by adding $80 \%$ of the acetic acid and the total amount of the other volatile fatty acids (JARL 1 947). The monensin content of the concentrate mixture was determined at Elanco's laboratory in England.

\section{Results}

Feed intake and growth rate

The intake of silage (Table 2) was low; of the total DM consumed, only 16.6 $\%$ originated from silage. This is partly due to the quality of the silage, which was harvested at the late growth stage. The total DM intake was 4.7 and $4.4 \mathrm{~kg}$ per head per day in the control and monensin groups, respectively. The test groups 
Table. 1. Chemical composition and feed values of the feedstuffs.

\begin{tabular}{lccc}
\hline & \multicolumn{3}{c}{ Feedstuffs } \\
\cline { 2 - 4 } & $\begin{array}{c}\text { Control } \\
\text { concentrate }\end{array}$ & $\begin{array}{c}\text { Monensin } \\
\text { concentrate }\end{array}$ & Silage* \\
\hline Dry matter, \% & 88.9 & 88.6 & 19.6 \\
In DM, \%: & 8.9 & 8.9 & 8.0 \\
Ash & 16.9 & 16.9 & 14.1 \\
Crude protein & 4.9 & 4.8 & 6.4 \\
Ether extract & 8.0 & 8.1 & 35.9 \\
Crude fibre & 61.3 & 61.3 & 35.6 \\
NFE & 1.05 & 1.05 & 0.68 \\
FFU/kg DM** & 12.0 & 12.0 & 9.0 \\
ME, MJ/kg DM & 135 & 135 & 87 \\
DCP, g/kg DM & & & \\
\hline
\end{tabular}

- In silage freshmatter: $\mathrm{pH} 3.92$, acetic acid $0.54 \%$, propionic acid $0.08 \%$ and butyric acid $0.02 \%$, OMdigestibility in vitro $65.4 \%$.

* FFU $=$ fattening feed unit $(0.7 \mathrm{~kg}$ starch equivalents)

Table 2. Live weight, daily weight gain, feed consumption and feed conversion rate of the control and monensin groups.

\begin{tabular}{lcc}
\hline & \multicolumn{2}{c}{ Group } \\
\cline { 2 - 3 } & Control & Monensin \\
\hline Number of bulls & 29 & 30 \\
Days in trial & 112 & 112 \\
Initial weight, $\mathrm{kg}$ & 79.7 & 79.1 \\
Final weight, $\mathrm{kg}$ & 228.2 & 228.0 \\
Daily weight gain, $\mathrm{g} / \mathrm{d}$ & 1328 & 1329 \\
Feed consumption, $\mathrm{kg} / \mathrm{d}:$ & 3.7 & \\
$\quad$ Concentrate & 0.8 & 3.9 \\
Silage & 4.7 & 0.7 \\
Total DM & 4.65 & 4.4 \\
FFU/d & 54.4 & 4.36 \\
ME, MJ/d & & 50.9 \\
Feed conversion rate, & 3.50 & 3.28 \\
FFU/kg gain & &
\end{tabular}

consumed $5.3 \%$ less concentrate DM, $7.3 \%$ less silage DM, $6.2 \%$ less fattening feed units and $6.4 \%$ less ME than the control groups.

The daily weight gain was the same in the test and control groups, 1328 and $1329 \mathrm{~g} / \mathrm{d}$. The feed conversion rate for the monensin groups was better than for the control groups, the difference in fattening feed units being $6.3 \%$.

Health of the bulls

The health of the animals was good, although one calf of the total 60 was removed from the experiment due to diarrhoea and poor growth (control group).

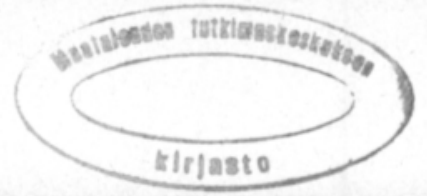




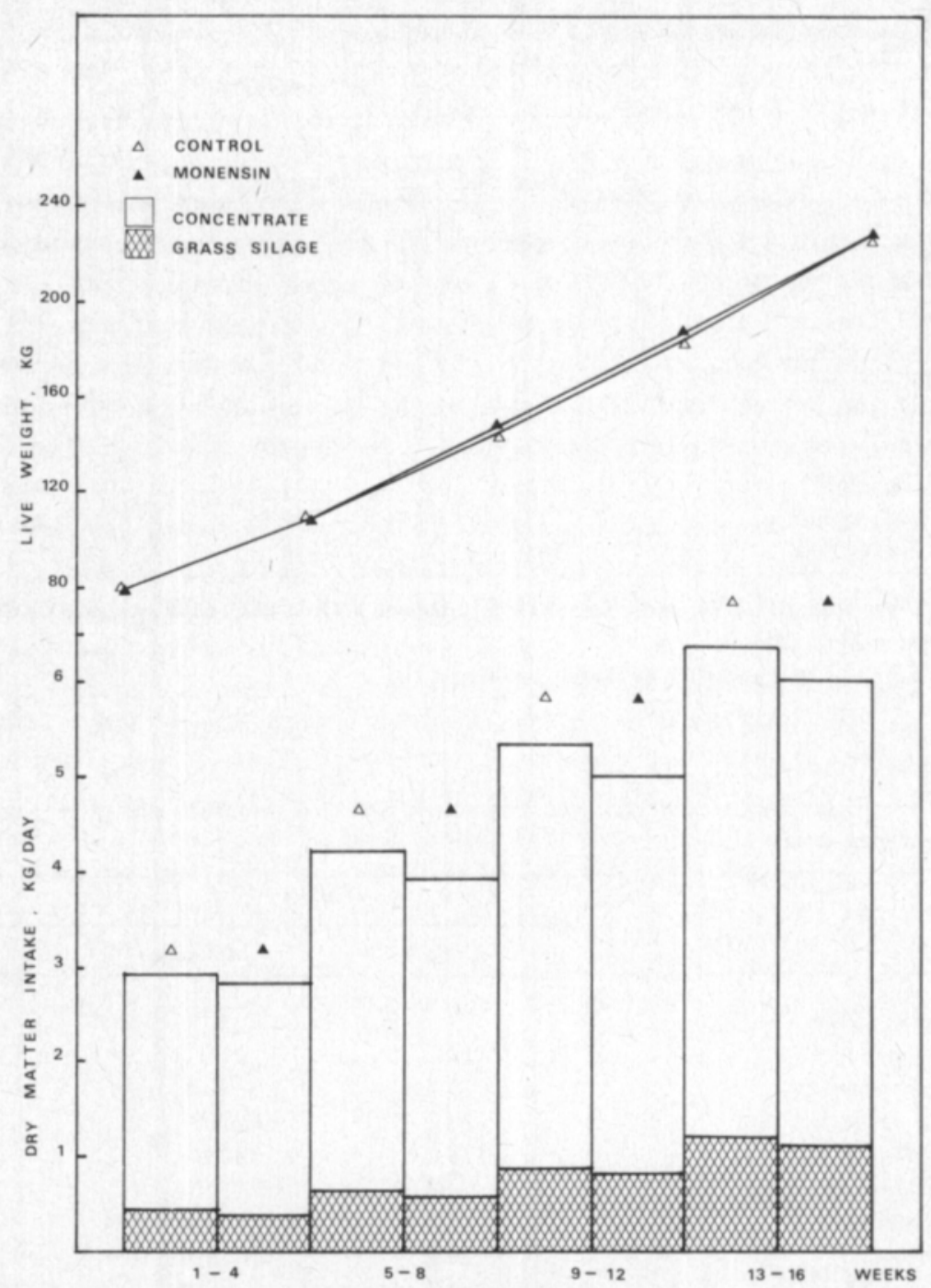

Fig. 1. Feed intake and live weight during the experiment.

The animals in the monensin pens were cleaner than the animals of the control groups. The calves were scored on a cleanness scale $(1=$ clean $-5=$ very dirty $)$ twice at weighings. The control groups had an average score of 2.9 and the monensin groups a score of 1.7 .

Faeces samples from each pen were examined twice for parasites during the experiment. No nematode eggs, lungworm larvae or coccidia oocysts were found.

\section{Discussion}

No effect of monensin on the cleanness of the animals has been reported earlier. Monensin probably decreases the amount of faeces and/or the amount of water in the faeces or urine. 
In this study the daily live weight gain was not affected by monensin which agrees with the results of HOLZER (1979), but not with those of LEVY et al. (1979) or MARTINSON and LINDELL (1981). In the GDR the effect of monensin on the growth of bulls crossbred from dairy cattle has been variable (HENNING et al. 1979, RICHTER et al. 1981). On ad libitum feeding there seems to be no common factor explaining the improvement of feed utilization by monensin. For instance, in the study of LEVY et al. (1979) monensin increased the daily weight gain of 3-month-old Israeli Friesian male bulls fed concentrate ad lib. and $0.5 \mathrm{~kg}$ hay per day. In contrast, HOLZER et al. (1979) found that monensin depressed the feed intake, but had no effect on the daily weight gain of male beef bulls aged about half a year. These also received concentrate ad lib, but the daily hay ration was 1.4 $\mathrm{kg}$.

The present increase of feed utilization $(6 \%)$ caused by monensin was slightly lower than in other experiments with bulls (HENNIG et al. 1979, HOLZER et al. 1979, MARTINSON and LINDELL 1981, RICHTER et al. 1981). The bulls in our experiment were younger, however, and proportion of roughage was lower.

The results show that monensin improves feed utilization immediately after weaning and that this effect is about the same or slightly weaker than later during the fattening period.

Acknowledgements. This study was supported financially by Elanco. The experimental feeds were mixed by Hankkija Feed Mill, Seinajjoki, and the VFA determinations on the silage samples were done by the laboratory of the Farmos Group Co., for which we are very grateful. Our special thanks are due to Mr. Hermanni Kulmala, for taking care of the experimental animals, to Mr. Antti Sipilä, B. Agr. Sci., for putting the animals and housing facilities at our disposal, to Mr. Tuomas Kulmala and Mr. Urho Riihikoski, Veterinarians, for health checking and cleanness scoring, and to Mr. Sven Nikander, Veterinarian, for the parasitological examinations.

\section{References}

BEEDE, D. K., GILL, W. W., KOENIG, S. E., LINDSEY, T. O., SCHELLING, G. T., MITCHELL, G. E. Jr. \& TUCKER, R. E. 1980. Nitrogen utilization and fiber digestibility in growing steers fed a low protein diet with monensin. J. Anim. Sci. 51. suppl. 1: 5 (Abstr.).

GARRETT, W. N., HINMAN, N. \& NADER, G. A. 1980. Net energy of alfalfa as influenced by monensin. J. Anim. Sci. 51, suppl. 1: 361 (Abstr.).

GILL, D. R., MARTIN, J. R. \& LAKE, R. 1976. High, medium and low corn silage diets with and without monensin for feedlot steers J. Anim. Sci. 43: 363-368.

HENNIG, A., FLACHOWSKY, G., WOLFRAM, D., STUBENDORFF, G., GEISSLER, Ch., FLACHOWSKY, E. \& RICHTER, G. 1979. Untersuchungen zum Einsatz des Pansenfermoregulators "Monensin" in der Mastbullenfütterung. Arch. Tierernähr. 29: 731-741.

HOLZER, Z., ILAN, D. \& LEVY, D. 1979. A note on the effects of monensin on the performance and on rumen metabolites of intact male cattle. Anim. Prod. 28: 135-137.

HORTON, G. M. 1980. A note on the effect of monensin and amicloral in steer diets. Anim. Prod. 30: 441444.

- BASSENDOWSKI, K. A. \& KEELER, E. H. 1980. Digestion and metabolism in lambs and steers fed monensin with different levels of barley. J. Anim. Sci. 50: 997-1008.

- \& NICHOLSON, H. H. 1980. Rumen metabolism and feedlot responses by steers fed tylosin and monensin. Can. J. Anim. Sci. 60: 919-924.

HUIDA, L. 1973. Quantitative determination of volatile fatty acids from rumen sample and silage by gasliquid chromatography. J. Scient. Agric. Soc. Finl. 45: 483-488.

JARL, F. 1947. Metodik vid ensileringsförsök. Nord. Jordbr. Forskn. Ber. 7. kongr. Oslo, 284-296. 
JOYNER, A. E., Jr., BROWN, L. J., FOGGT, T. J. \& ROSSI, R. T. 1979. Effect of monensin on growth, feed efficiency and energy metabolism of lambs. J. Anim. Sci. 48: 1065-1069.

LEVY, D., HOLZER, Z. \& ILAN, D. 1979. Monensin supplementation of young israeli friesian male cattle. Anim. Prod. 29: 305-310.

MARTINSSON, K. \& LINDELL, L. 1981. Feeding experiment with Rumensin to growing bulls. Swed. J. Agric. Res. 11: 23-27.

PALOHEIMO, L. 1969. Weender Analyse. In: Handbuch der Tierernährung I, ed. W. Lenkeit, K. Breirem and E. Craseman. Hamburg, p. 164-171.

RAUN, A. P., COOLEY, C. O., POTTER, E. L., RATHMACHER, R. P. \& RICHARDSON, L. F. 1976. Effect of monensin on feed efficiency of feedlot cattle. J. Anim. Sci. 43: 670-677.

RICHARDSON, L. E., RAUN, A. P., POTTER, E. L., COOLEY, C. O. \& RATHMACHER, R. P. 1976. Effect of monensin on rumen fermentation in vitro and in vivo. J. Anim. Sci. 43: 657-664.

RICHTER, G., GENTZSCH, W., LÖHNERT, H.-J. \& FLACHOWSKY, G. 1981. Der Einfluss des Polyätherantibiotikums "Monensin" auf Pansenfermentation und Mastergebnisse von Milchrindkreuzungsbullen und Masthybriden. Arch. Tierernāhr. 31: 57-65.

THORNTON, J. H. \& OWENS, F. N. 1981. Monensin supplementation and in vivo methane production by steers. J. Anim. Sci. 52: 628-634.

TILLEY, J. M. \& TERRY, R. A. 1963. A two-stage technique for the in vitro digestion of forage crops. J. Brit. Grassld. Soc. 18: 104-111.

WEDEGAERTNER, T. C. \& JOHNSON, D. E. 1980. Effect of monensin on energy metabolizability and retention of a high grain diet fed to steers. J. Anim. Sci. 51, suppl. 1: 408 (Abstr.).

Ms received October 12, 1981.

SELOSTUS

\section{Monensin-ruokintakoe kasvavilla sonneilla}

\section{Mikko Tuori ja Liisa Syrjälä-Qvist}

Helsingin yliopiston kotieläintieteen laitos, 00710 Helsinki 71

Streptomyces cinnamonensis -mikrobin tuottaman antibiootin monensinin vaikutusta kasvuun ja rehun muuntosuhteeseen tutkittiin 60 kasvavalla sonnilla. Eläimet olivat etupäässã ay-rotuisia välitysvasikoita, jotka kokeen alkaessa olivat $2-3$ kuukauden ikäisiā. Eläimet olivat ulkopihatossa jaettuna neljään karsinaan, joista kaksi karsinaa sai 35 ppm monensinia sisältãvãã täysrehua ad lib. ja toiset kaksi samaa tãysrehua ilman monensinia. Syyssadosta tehtyä ruohosäilörehua annettiin myös vapaasti. Koe kesti 16 viikkoa. Monensinryhmān rehunkulutus oli kontrolliryhmää alempi, väkirehua vastaavasti 3.7 ja $3.9 \mathrm{~kg} \mathrm{ka/d}$, säilörehua 0.7 ja 0.8 $\mathrm{kg} \mathrm{ka/d}$ sekä laskettu rehuyksikkökulutus 4.36 ja 4.65 ry/d. Kun ryhmien kesken ei ollut eroja päivittäisessä lisäkasvussa (1 329 ja $1328 \mathrm{~g} / \mathrm{d}$ ), muodostui rehun muuntosuhde (3.28 ja $3.50 \mathrm{ry} / \mathrm{kg}$ lisākasvua) monensinryhmällä $6.3 \%$ kontrolliryhmää paremmaksi.

Eläinten terveys oli kokeessa koko ajan suhteellisen hyvä, vaikkakin yksi kontrolliryhmän vasikka poistettiinkin kokeesta pitkäaikaisen ripulin tähden. Karsinoista kerätyistä sontanäytteistä ei tavattu tutkittuja tavallisimpia parasiitteja. Monensin-ryhmän eläimet pysyivät hieman kontrollieläimiä puhtaampina johtuen todennäköisesti pienemmistä sonnan tai sonnassa ja virtsassa erittyneen veden määristä. 